\section{Illusion in ascent}

Peter J. Bowler

Taking Darwin Seriously: A Naturalistic Approach to Philosophy. By Michael Ruse. Basil Blackwell: 1986. Pp.303. $£ 22.50, \$ 24.95$.

Michael Ruse believes that scarcely anyone has taken Darwin seriously up to now. Efforts to apply evolutionism to the problems of philosophy have failed, largely because of a refusal to acknowledge the central tenet of Darwinism: the non-progressive character of natural selection. Whatever one's opinion of Darwinism (Ruse, of course, accepts it as the basis of all legitimate evolutionary thinking), the claim that the theory has seldom been taken seriously can certainly be endorsed by the historian. To depict the growth of evolution theory as a simple ascent from Darwinism to the Modern Synthesis is to fall into the worst kind of Whig history, ignoring the large number of thinkers, including scientists, who have found the principles of natural selection unacceptable. As Ruse points out, modern Darwinists from Julian Huxley to E.O. Wilson have also found it difficult to accept the non-progressionist character of the theory.

Ruse's purpose here is to address the philosophical, not the historical issues. $\mathrm{He}$ criticizes evolutionary approaches to the problem of knowledge, from Herbert Spencer to Karl Popper. Drawing a simple analogy between evolution and the growth of science does not work, he says, because science is progressive and evolution is not. He looks instead at the kind of reasoning that we might expect natural selection to have programmed into our ancestors so that they could deal successfully with the real world. We believe that an effect must follow its cause, because any of our ancestors who did not have this mental reinforcement to back up their perception of causal regularities would soon have disappeared. The intellectual ancestor of this approach is David Hume, who realized that we read necessity into nature even though we have no philosophically satisfactory guarantee that there is anything corresponding to that

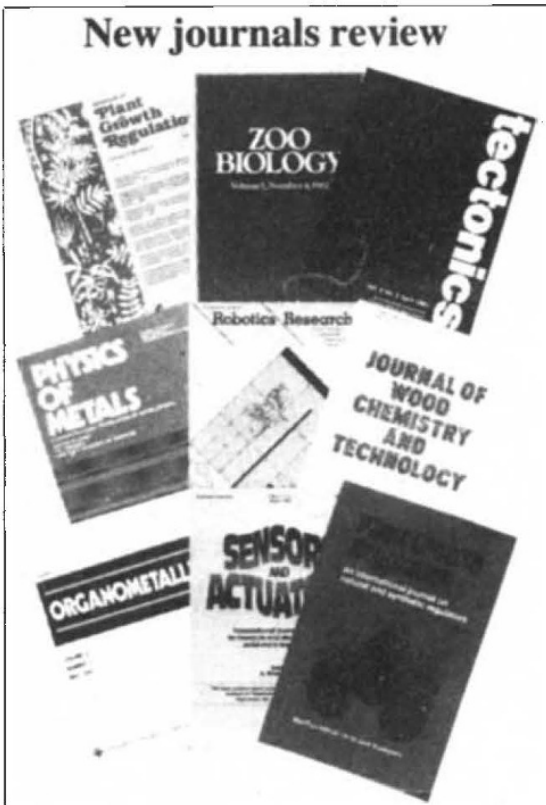

On 25 September Nature will publish the sixth annual review supplement devoted to science journals.

Criteria for inclusion of a journal in the 1986 issue are that:

(i) the first number appeared, or the journal was retitled, between June 1984 and May 1985 (the second cut-off date allows at least three issues of a journal to have been published, the minimum number on which a reasonable judgement can be based);

(ii) it is published at least three times a year;

(iii) the main language used is English.

Publishers and learned societies are invited to send four different issues of each suitable periodical, including the first and most recent numbers (if from outside the United Kingdom, by air mail) to: The Review Editor, Nature, 4 Little Essex Street, London WC2R 3LF, England. Subscription details for both 1986 and 1987 should be included.

\section{RÖNNELLS} to understand the character of such restraints. As we move into a world that differs ever more radically from that in which our ancestors evolved, such insights may help us to come to terms with the philosophical problems that confront us.

Peter J. Bowler is a Lecturer in the Department of History and Philosophy of Science, Queen's University of Belfast, Belfast BT7 INN, UK

philosophers are not satisfied with this, Ruse tells them that they will have to go presumably not be happy with a viewpoint anyone who has lost patience with the apparently endless wrangling of academic On the question of morality, Ruse is
. critical of "social Darwinism" and other evolution, precisely because they invaritowards some ultimate good. His own approach starts from the principles of socionants of progressionism from the work of have endowed us with epigenetic rules inining us to behave in a socially respon-

Scientific Books 89 Periodicals

For current catalogues:

No. 55

HISTORY OF MEDICINE

No. 56

AMERICANA

and other subjects

write:

RÖNNELLS

Birger Jarlsg. 32

11429 Stockholm

\section{IMAGE \\ UNAVAILABLE \\ FOR \\ COPYRIGHT \\ REASONS}

Work of worms - section through a fallen Druidical stone at Stonehenge, indicating how much it has sunk into the ground through the undermining action of earthworms. Depth of the stone is c. $30 \mathrm{~cm}$. The illustration is taken from a new paperback edition of Charles Darwin's The Formation of Vegetable Mould, through the Action of Worms (1881), published by University of Chicago Press. Price is \$12, f10.25. For review see Nature 24, 553-556 (1881). 